\title{
Medicinal Plants of North East India: Does the Answer Lies Within
}

\author{
Pratim Sarma M*, Munim F, Bhattacharjee M \\ Department of Biotechnology, Assam down town University, Panikhaiti, Assam, \\ India
}

*Corresponding Address: Manash Pratim Sarma, Assistant Professor, Department of Biotechnology; Assam down town University; Assam; India, Tel: 91-8255075275; Email: manash3268@gmail.com

\section{Abstract}

Medicinal plants are the most common reservoir of life saving drugs for the world. They are still considered to be efficient in treating the diseases of mankind. India has a rich and diverse flora of flowering medicinal plants. The use of plants as medicines is practiced from ancient times to the recent days. The current study is aimed to find out the phytochemical content of 5 medicinal plants of NE India namely Mimosa pudica, Catharanthus roseus, Ocimum tenuiflorum, Centella asiastica, Tagetes erecta. It was found that steroids were present only in the leaves of Mimosa pudica and was not found in any other part of the five studied plants. Terpenoids were most commonly observed in the root part of the studied plants. The results for flavonoids were of mixed nature. Flavonoids were found to be positive by alkaline reagent test in most part of the studied plants. However flavonoids could not be detected in few parts of the selected plants by the other qualitative detection method known as the hydrogen sulphide test. There were mixed results for the presence of the phytochemicals such as tannins, glycosides and coumarins in various parts of the above studied plants. Similarly proteins, carbohydrates and amino acids were detected in various parts of the studied medicinal plants

Keywords: Phytochemicals; Medicinal plants; North East India; Protein estimation

\section{Introduction}

The plant of Mimosa pudica, Catharanthus roseus, Ocimum tenuiflorum, Centella asiastica, Tagetes erecta and many more medicinal plants has a very great medicinal value. These plants have been mostly studied with respect to its anticancer, anti hypertension and anti diabetic properties. Therefore, it is very essential to develop alternative ways for treating various infections such as by using medicinal plants.
Herbal medicine which is also known as phytomedicine or botanical medicine -refers to the use of plants seeds, flowers, roots for medicinal purpose. Herbalism has been in use since a longer time than allopathic medicine. By the improvements in analysis and quality control, their use is becoming more prevailing. The mode of action of these plants is distinct to a particular plant species, due to the fact that the 


\section{Bioequivalence \& Bioavailability International Journal}

combination of secondary metabolites in a particular plant is taxonomically unique. The detailed account of the 5 plants selected for the current study is provided as supplementary file $[1,2]$.

\section{Review of Literature}

Reda F, et al. performed a study on different stages of fruiting and flowering of Catharanthus roseus and investigated the accumulation of alkaloids and the pattern distribution in them. The roots showed the highest amount of alkaloids at the start of flowering and the minimum in the stems during full fruiting stage. A decrease in the concentration of alkaloids in the leaves, stems and roots during maturation of fruit was observed. During the start of flowering, the alkaloid biosynthesis is highest in all vegetative organs Misra N, et al. 1996 studied the process of indole alkaloid synthesis in Catharanthus roseus. Vinblastine (VLB), vincristine (VCR) and ajmalicine were found to be the most beneficial Catharanthus alkaloids. VLB and VCR are known to have ant cancerous properties whereas ajmalicine is known for its use in treating circulatory diseases. Three enzymes of 20 monomeric indole alkaloids have also been studied at molecular levels. Ploeg, 1999, studied on greenhouse effects of marigolds (Tagetes species).In another study, the same group studied the Meloidogyne incognita by Tagetes cultivars and investigated the effect of temperature on suppression. It was concluded that marigolds should be grown at soil temperatures above $15{ }^{\circ} \mathrm{C}$ to suppress $M$. incognita infection. Kimpinski et al., 2000, have made a study on the effects of Marigold and various cover crops on the nematodes and on following Potato crops. It was concluded that levels of root-lesion nematodes were lower under marigolds than the other cover crops tested. Observed if the populations of Pratylenchus penetrans in potato and tomato could be suppressed by using African Marigolds. The results suggested that $P$. penetrans population density could be significantly suppressed in potato or tomato roots when they are followed by marigolds [3-5].

Sreevalli, et al. 2002 carried out a study on the inheritance pattern of an uncommon flower color. The results confirmed the involvement of two more genes which are interacting and independently inherited. One (proposed symbol E) was determining the presence or absence of red eye and another was determining orange-red corolla (proposed symbol 0).

Filippini et al. 2003 carried out a research and studied the production of anthocyanins by C. roseus. Anthocyanins were compared with the one synthesized in the flowers. The relative content was found to be similar. However the total content was lower in the suspension culture. Similar studies were carried out by carried out similar studies on C. roseus [6-10].
Mimosa pudica is another plant which is widely studied for its uses in folklore medicine for blood coagulation and in treating skin diseases. Ocimum sanctum is also studied by various groups for its potential beneficial effect in neuropathic pain [11-16]. Tagetes erecta has been another important medicinal plant that has been studied by many groups and studies on animal models have been carried out [17].

\section{Aim and Objectives}

The current study was aimed with the following objectives.

1. To study the phytochemical analysis and evaluation of leafs, stems, roots and flowers of medicinal herbs.

2. To estimation the amount of protein present in leafs, stems, roots and flowers of the medicinal plants by Lowry's methods.

The study is of utmost importance as these medicinal plants are predominantly found in NE region of India which is also a biodiversity hotspot in terms of medicinal use as well as economy point of view.

\section{Materials and Methods}

The experiment was conducted in the Department of Biotechnology, down town College of Allied Health Sciences, Panikhaiti, Guwahati, Assam.

\section{Materials}

Plants Sample: The plant of Mimosa pudica, Catharanthus roseus, Ocimum tenuiflorum, Centella asiastica, Tagetes erecta was collected from different areas of Kamrup district of Assam, India during the month of February- March, 2015.

\section{Chemical Reagents and Buffer}

Gallic acid, Quercetin, sodium carbonate(10\%), 10\% aluminium chloride( $\mathrm{AlCl} 3)$, sodium nitrate $\left(\mathrm{NaNO}_{2}\right)$, sodium hydroxide( $\mathrm{NaOH})$, hydrogen peroxide $\left(\mathrm{H}_{2} \mathrm{O}_{2}\right)$, Folin-Ciocalteu(F-C)reagent, ascorbic acid(Vit C), 95\% ethanol, isoamylalcohol, benzene, ammonium hydroxide, $1 \%$ lead acetate, hydrochloric acid, sulphuric acid, sodium carbonate and Phosphate Base Saline(PBS).

\section{Glasswares and Plasticwares}

The glassware used in the study was procured from Borosil (India) and Plasticwares including microtips, sterilized centrifuge tubes were procured from Tarson. The Glasswares and Plasticwares were washed thoroughly. The Glasswares was sterilized in hot air oven at 160c for 6hours and Plasticwares were sterilized by autoclaving. 


\section{Bioequivalence \& Bioavailability International Journal}

\section{Equipments}

Some of the important equipments utilized for the study included:

ANAMED Electronic Balance (Model; M-300, A named Instruments Pvt. Ltd. India), UV Vis Spectrophotometer (Model-UV/VIS 711, pipettes, micropipettes, Centrifuge(REMI,8-C), and -70c Temperature Freezer (operon-ultra-flow) were the major equipments used in the study.

\section{Methods}

\section{Preparation of Extracts}

Solvent extraction: The leaves, stems, roots of above medicinal plants and flowers of Catharanthus roseus were collected and washed. The water extraction was carried out using classical method, where grinded plant material of $3 \mathrm{gm}$ weighed using an electronic balance and was crushed in $100 \mathrm{ml}$ of sterile water. Then the mixture was boiled at $50-60^{\circ} \mathrm{C}$ for 30 minutes on water bath and it was filtered through Whatman No.1 filter paper. Then the filtrate was centrifuged at $2500 \mathrm{rpm}$ for 15 minutes. The extracts was collected, labeled and stored at $5^{\circ} \mathrm{C}$ for further experimental use [18-24].

Qualitative analysis of phytochemicals: The extracts were subjected to qualitative analysis for presence of chemical constituents by performing various chemical tests.

\section{Test for Steroids}

Salkowski Test - $1 \mathrm{ml}$ of the extract was dissolved in $10 \mathrm{ml}$ of chloroform and equal volume of concentrated H2SO4 was added by sides of the test tube. The upper layer turns red and sulphuric acid layer showed yellow with green fluorescence. This indicated the presence of steroids.

\section{Test for Terpenoids}

Salkowski Test - $1 \mathrm{ml}$ of the extract was added to $1 \mathrm{ml}$ of chloroform and filtered. To the filtrate $1 \mathrm{ml}$ of acetic acid was added and then few drops of concentrated H2SO4 run down the side of test tube. Pink or pinkish brown colour shows presence of terpemoids.

\section{Test For Flavonoids}

Alkaline Reagent Test - Extracts were treated with few drops of sodium hydroxide solution. Formation of intense yellow colour, which becomes colourless on addition of dilute acid, indicates the presence of flavonoids.
H2so4 Test - A fraction of extract was treated with concentrated $\mathrm{H} 2 \mathrm{SO} 4$ and observed for the formation of orange colour.

Lead Acetate Test - A small amount of extract was treated with lead acetate and observed for the formation of white precipitate.

\section{Test for Tannins}

Lead Acetate Test - $2 \mathrm{ml}$ of extract was added to few drops of $1 \%$ lead acetate. A yellowish precipitate indicates the presence of tannins.

\section{Test for Glycosides}

Keller-Kiliani Test - $5 \mathrm{ml}$ of extract was dissolved in 2 $\mathrm{ml}$ chloroform. To that few drops of dilute H2SO4 was added to form a layer. A brown ring at the interface indicates the presence of glycosides.

\section{Test for Coumarins}

$3 \mathrm{ml}$ of $10 \% \mathrm{NaOH}$ was added to $2 \mathrm{ml}$ of aqueous extract. Formation of yellow colour indicates the presence of coumarins.

\section{Test for Carbohydrates}

Extracts were dissolved individually in $5 \mathrm{ml}$ distilled water and filtered. The filtrates were used to test for the presence of carbohydrates.

Benedict's Test - Filtrates were treated with Benedict's reagent and heated gently. Orange red precipitate indicates the presence of reducing sugars.

Fehling's Test - Filtrates were hydrolysed with dilute $\mathrm{HCl}$, neutralized with alkali and heated with Fehling's A and B solutions. Formation of red precipitate indicates the presence of reducing sugars.

\section{Test for Proteins and Amino Acids}

Xanthoproteic Test - The extracts were treated with few drops of concentrated Nitric acid. Formation of yellow colour indicates the presence of proteins.

Ninhydrin Test - To the extract, $0.25 \% \mathrm{w} / \mathrm{v}$ ninhydrin reagent was added and boiled for few minutes. Formation of blue colour indicates the presence of amino acids.

\section{Estimation of Protein By Lowry's Method}

The standard procedure of Lowry's method was followed and the amount of the protein is estimated.

\section{Results}

Nature of the extracts: The colour of the water extract of different parts of following plants like Mimosa pudica, Catharanthus roseus, Ocimum tenuiflorum, Centella 
asiastica, Tagetes erecta have same distinct colour which are tabulated below

\begin{tabular}{|c|c|c|c|c|}
\hline \multirow{2}{*}{ Extract } & \multicolumn{3}{|c|}{ Color } \\
\cline { 2 - 4 } & Leaf & Stem & Root & Flower \\
\hline Water Extract & Reddish & Brown & Light brown & Dark Brown \\
\hline
\end{tabular}

Table 1: Nature of the extract

\section{Phytochemical Analysis}

Preliminary qualitative phytochemical screening of extracts was carried out with the following methods: Salkowski test, Alkaline reagent test, $\mathrm{H}_{2} \mathrm{SO}_{4}$ test, Lead acetate test, Keller-kiliani test, Benedict's test, Fehling's test, Xanthoproteic test, and Ninhydrin test. The results for the test are summarized in table2:

\begin{tabular}{|c|c|c|c|c|c|c|c|c|c|c|c|c|c|}
\hline \multirow{2}{*}{$\underset{\stackrel{n}{\Xi}}{\stackrel{0}{a}}$} & \multirow{2}{*}{ 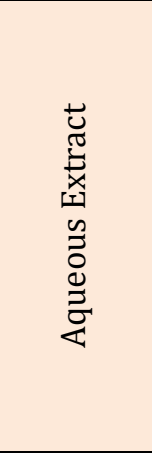 } & \multirow{2}{*}{ 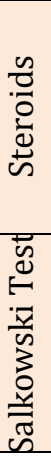 } & \multirow{2}{*}{ 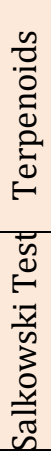 } & \multicolumn{3}{|c|}{$\begin{array}{l}0 \\
0 \\
0 \\
0 \\
0 \\
\frac{\pi}{I}\end{array}$} & \multirow{2}{*}{ 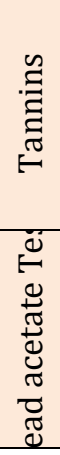 } & \multirow{2}{*}{ 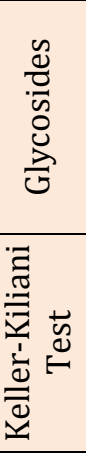 } & \multirow{2}{*}{ 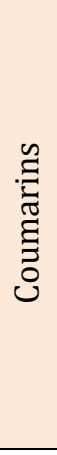 } & \multicolumn{2}{|c|}{ 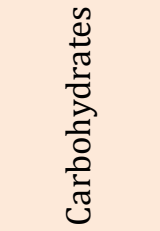 } & \multirow{2}{*}{ 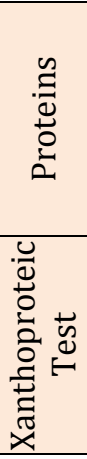 } & \multirow{2}{*}{ 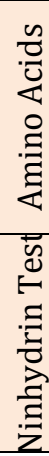 } \\
\hline & & & & 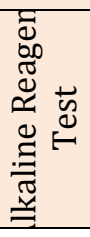 & 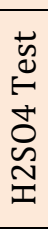 & 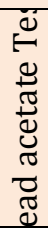 & & & & 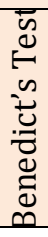 & 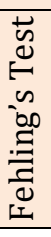 & & \\
\hline \multirow{3}{*}{ Mimosa pudica } & LEAF & + & - & + & + & - & + & - & + & - & + & + & - \\
\hline & STEM & _ & $\ldots$ & + & _ & $\ldots$ & + & $\ldots$ & + & + & + & - & + \\
\hline & ROOT & _ & + & + & $\ldots$ & + & $\ldots$ & $\ldots$ & - & + & + & + & + \\
\hline \multirow{4}{*}{$\begin{array}{c}\text { Catharanthus } \\
\text { roseus }\end{array}$} & LEAF & - & - & + & + & + & - & - & + & - & - & - & + \\
\hline & STEM & _ & _ & + & $\ldots$ & _ & _ & _ & $\ldots$ & _ & $\ldots$ & _ & + \\
\hline & ROOT & $\ldots$ & $\ldots$ & $\ldots$ & $\ldots$ & $\ldots$ & $\ldots$ & - & $\ldots$ & $\ldots$ & + & + & + \\
\hline & FLOWER & _ & + & + & + & + & + & _ & + & + & + & + & $\ldots$ \\
\hline \multirow{3}{*}{$\begin{array}{l}\text { Ocimum } \\
\text { tenuiflorum }\end{array}$} & LEAF & - & - & - & - & - & + & + & + & + & + & + & - \\
\hline & STEM & $\ldots$ & $\ldots$ & $\ldots$ & $\ldots$ & + & $\ldots$ & _ & $\ldots$ & _ & $\ldots$ & $\ldots$ & _ \\
\hline & ROOT & - & - & + & + & + & 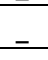 & - & - & - & + & 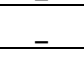 & - \\
\hline \multirow{3}{*}{ Centella asiatica } & LEAF & - & - & + & + & + & + & - & + & + & + & - & - \\
\hline & STEM & _ & _ & _ & + & + & _ & _ & _ & _ & + & _ & _ \\
\hline & ROOT & $\ldots$ & $\ldots$ & + & + & + & + & _ & + & $\ldots$ & + & $\ldots$ & _ \\
\hline \multirow{3}{*}{ Tagetes erecta } & LEAF & - & - & + & - & - & + & - & + & - & + & + & + \\
\hline & STEM & $\ldots$ & $\ldots$ & + & $\ldots$ & $\ldots$ & + & _ & + & _ & + & _ & _ \\
\hline & ROOT & _ & $\ldots$ & - & $\ldots$ & & + & & - & & + & & \\
\hline
\end{tabular}

Table 2: Phytochemicals analysis of five plants.

It was found that steroids were present only in the leaves of Mimosa pudica and was not found in any other part of the five studied plants. Terpenoids were most commonly observed in the root part of the studied plants. The results for flavonoids were of mixed nature. Flavonoids were found to be positive by alkaline reagent test in most part of the studied plants. However flavonoids could not be detected in few parts of the selected plants by the other qualitative detection method known as the hydrogen sulphide test.

There were mixed results for the presence of tannins, glycosides and coumarins in various parts of the studied plants. Similarly proteins, carbohydrates and amino acids were detected in various parts of the studied medicinal plants as depicted in table 2, 3 and 4 and Figure 1-5. 

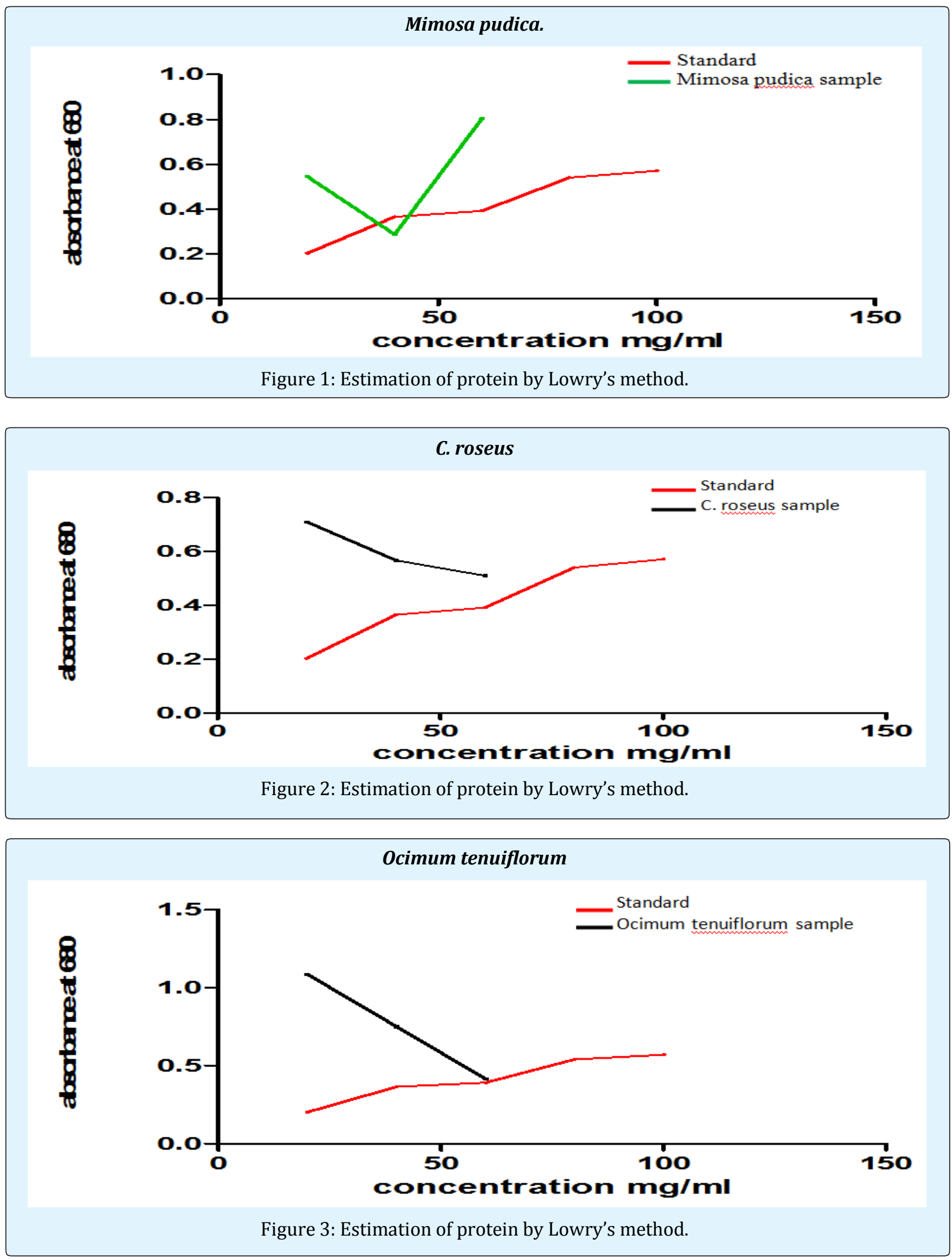


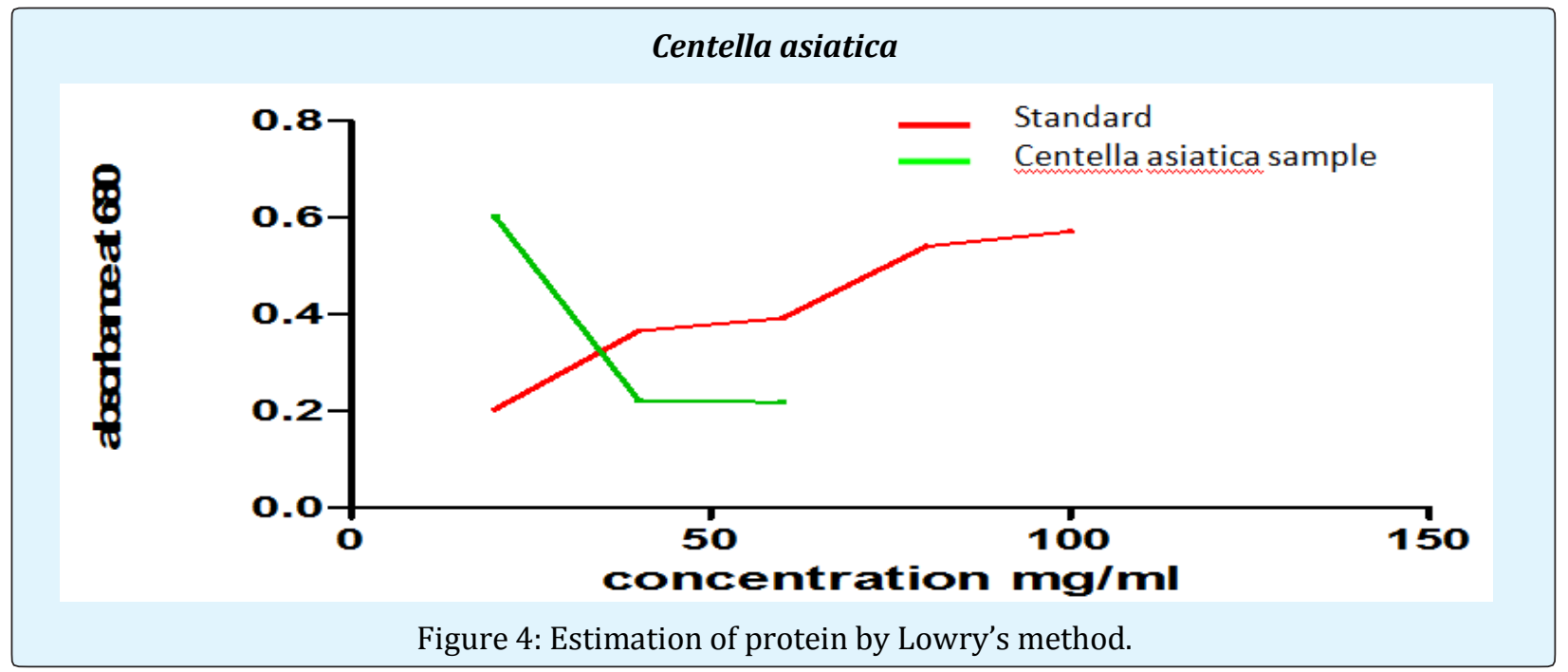

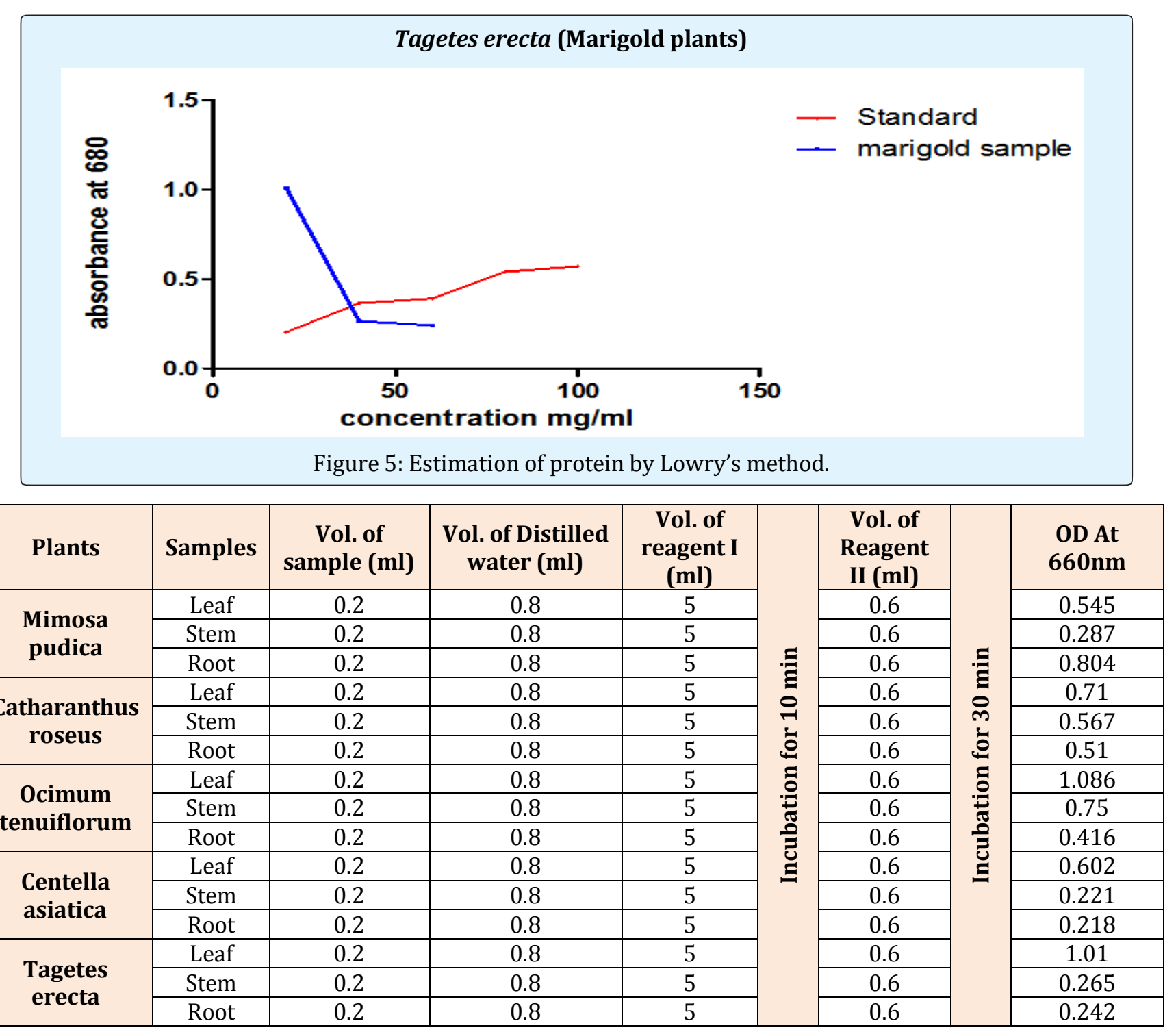

Table 3: Lowry's test of the samples 


\begin{tabular}{|c|c|c|c|}
\hline \multirow{2}{*}{ Plants } & \multicolumn{3}{|c|}{ Protein concentration } \\
\cline { 2 - 4 } & Leaf & Stem & Root \\
\hline Mimosa pudica & $24 \mathrm{mg} / \mathrm{ml}$ & $39 \mathrm{mg} / \mathrm{ml}$ & $63 \mathrm{mg} / \mathrm{ml}$ \\
\hline Catharanthus roseus & $20 \mathrm{mg} / \mathrm{ml}$ & $40 \mathrm{mg} / \mathrm{ml}$ & $60 \mathrm{mg} / \mathrm{ml}$ \\
\hline Ocimum tenuiflorum & $19 \mathrm{mg} / \mathrm{ml}$ & $39 \mathrm{mg} / \mathrm{ml}$ & $59 \mathrm{mg} / \mathrm{ml}$ \\
\hline Centella asiatica & $17 \mathrm{mg} / \mathrm{ml}$ & $41 \mathrm{mg} / \mathrm{ml}$ & $60 \mathrm{mg} / \mathrm{ml}$ \\
\hline Tagetes erecta & $22 \mathrm{mg} / \mathrm{ml}$ & $40 \mathrm{mg} / \mathrm{ml}$ & $63 \mathrm{mg} / \mathrm{ml}$ \\
\hline
\end{tabular}

Table 4: Protein concentration

\section{Discussion}

The five medicinal plants that we have examined areMimosa pudica, Catharanthus roseus, Ocimum sanctum, Centella asiatica and Tagetes erecta. The medicinal values of these plants are vary. The therapeutic value of medicinal plants lies in the various chemical constituents in it. The bioactivity of plant extracts is attributed to phytochemical constituents.

By observing Phytochemicals analysis of the leaf, stem and root extract of Mimosa pudica, we have observed the positive results for the test Steroid, terpenoid, flavanoid, tannin, coumarin, carbohydrate, protein and amino acid. For the plant Catharanthus roseus, we have found positive results for terpenoid, flavanoid, tannin, coumarin, carbohydrate, protein and amino acid. Observing the plant Ocimum sanctum, we have found the positive results for flavanoid, tannin, glycoside, coumarin, carbohydrate and protein. For the plant Centella asiastica, we have observed the positive results for for terpenoid, flavanoid, tannin, coumarin and carbohydrate. By examining the plant Tagetes erecta, we have observed the positive results for terpenoid, tannin, coumarins, carbohydrate, protein and amino acid.

The medicinal values of these plants are-

Mimosa pudica-This plant is used widely in traditional medicine. Pulped leaves are used in India on glandular swellings and in the Republic of the Congo (CongoBrazzaville) the entire plant is pulped and rubbed onto people suffering pains in their body sides and kidneys. In Senegal, the leaves are used for lumbago and nephritis.

Catharanthus roseus-The plant is use in folklore remedies for treatment of diabetes, malaria, dengue fever, dysentery, insect bites, skin infection, diarrhea, leukemia, eye irritation, dyspepsia, dysentery, toothache, sore throat, and lung congestion. The root of the plant is reported to be a tonic and possess hypotensive, sedative, and tranquillizing properties. In Ayurveda, it is used for treating diabetes. Hypoglycemic activity of aqueous extracts from MP has been proved in modern studies, as well. In Madagascar, the bitter and astringent leaves have been applied as an emetic; roots have been used as a purgative, vermifuge, depurative, hemostatic agent and toothache remedy. In the Philippines, the leaf decoction is an herbal treatment for diabetes, young leaves are for stomach cramps, and root decoction is for intestinal parasitism. Mauritians employ infusion of leaves for indigestion and dyspepsia.

Ocimum sanctum- Holy Basil is very important herbs and has many medicinal applications. Tulsi is used in the treatment of various diseases. Basil plant and its various parts are used in case of insect bite, fever, cardiac diseases, gynecological disorders, respiratory problems, skin disorders, etc. It is good to prevent malaria and an effective pain killer. Tulsi leaves also act as a tonic for hearts.

Centella asiastica- it is used in Insomnia Include whole plant's paste in daily diet, Toothache, Sinusitis, Dysentery, Memory enhancement

Tagetes erecta- Tagetes is used for digestive tract problems including poor appetite, gas, stomach pain, colic, intestinal worms, and dysentery. It is also used for coughs, colds, mumps, fluid retention, and sore eyes; and causing sweating. Women use Tagetes to start menstruation, treat sore breasts (mastitis), and protect against miscarriage, treating sores and ulcers. The flowers are used as a mosquito repellent. The juice of the leaves is put on the skin for treating eczema. The oil is put on the skin for treating wound maggots. In foods and beverages, Tagetes is used as a flavor component. For the estimation of protein we have examined the plants with Lowry's method. The amount of protein varies in each of the plants [25-31].

The concentration of protein found in

- Mimosa pudica of leaf, stem, and root is $24 \mathrm{mg} / \mathrm{ml}, 39$ $\mathrm{mg} / \mathrm{ml}$, and $63 \mathrm{mg} / \mathrm{ml}$ respectively.

- Catharanthus roseus of leaf, stem, and root is 20 $\mathrm{mg} / \mathrm{ml}, 40 \mathrm{mg} / \mathrm{ml}$, and $60 \mathrm{mg} / \mathrm{ml}$ respectively.

- Ocimum sanctum of leaf, stem, and root is $19 \mathrm{mg} / \mathrm{ml}$, $39 \mathrm{mg} / \mathrm{ml}$, and $59 \mathrm{mg} / \mathrm{ml}$ respectively.

- Centella asiatica of leaf, stem, and root is $17 \mathrm{mg} / \mathrm{ml}$, $41 \mathrm{mg} / \mathrm{ml}$, and $60 \mathrm{mg} / \mathrm{ml}$ respectively. 
- Tagetes erecta of leaf, stem, and root is $22 \mathrm{mg} / \mathrm{ml}, 40$ $\mathrm{mg} / \mathrm{ml}$, and $63 \mathrm{mg} / \mathrm{ml}$ respectively.

\section{Conclusion}

The selected five medicinal plants are the source of the secondary metabolites i.e., alkaloids, flavonoids, terpenoids. Medicinal plants play an important role in treating various diseases. The antidiuretic, antiinflammatory, antianalgesic, anticancer, anti-viral, antimalarial, anti-bacterial and anti-fungal activities of the medicinal plants are due to the presence of the above mentioned secondary metabolites. Medicinal plants are used for discovering and screening of the phytochemical constituents which are very helpful for manufacturing new drugs. The previous phytochemical analysis and present studies show nearly the similar results due to the presence of the phytochemicals. The phytochemical analysis of the medicinal plants also has commercial interest in both research institutes and pharmaceuticals companies. Thus we hope that the important phytochemical properties identified by our study in the local plant of Assam will be helpful in the treating various diseases of this particular region.

\section{Hypothesis}

North East India has been termed as one of the richest biodiversity hotspot in the planet and is inhabitated by numerous tribes with different ethnicity and tribes. The folk medicine of this part has been an area of interest for many researchers working on herbal medicine. In this study we hypothesized that the traditionally used medicinal plants of NE has got many phytochemicals which make them good candidates for herbal medicine.

\section{Future Direction}

The huge and diversified resource of NE India can be optimally used to design drugs which will in turn serve the mankind.

\section{Prospective and Prediction}

The biochemical assays are currently followed by GCMS and LC MS studies. Study on animal model will further confirm the safety and efficacy of these medicinal plants.

\section{References}

1. Jaggi RK, Madaan R, Singh B (2003) Anticonvulsant potential of holy basil, Ocimum sanctum Linn., and its cultures. Indian J Exp Biol 41(11): 1329-1333.
2. El-Sayed A, Handy GA, Cordell GA (1983) Catharanthus alkaloids, Confirming structural evidence and antineoplastic activity of the bisindole alkaloids leurosine- $\mathrm{N}^{\prime}$-oxide (pleurosine), roseadine and vindolicine from Catharanthus roseus. J Nat Prod 46(4): 517-527.

3. Khaled A Shams, Naglaa M Nazif, Nahla S Abdel Azim, Khaled A Abdel Shafeek, Mostafa M ElMissiry, et al. (2009) Isolation and Characterization of Antineoplastic Alkaloids from Catharanthus Roseus L. Don. Cultivated in Egypt. Afr J Tradit Complement Altern Med 6(2): 118-122.

4. Mishra P, Kumar S (2000) Emergence of periwinkle Catharanthus roseus as a model system for molecular biology of alkaloids: phytochemistry, pharmacology, plant biology and in vivo and in vitro cultivation. Journal of Medicinal and Aromatic Plant Sciences 22(2-3): 306-337.

5. Qayoom A Mir, T Yazdani, S Ahmad and M Yunus, Total flavonoids and phenolics in Catharanthus roseus L. and Ocimum sanctum L. as Biomarkers of Urban Auto Pollution. Caspian J Env Sci 7(1): 9-16.

6. Singh SN, Vats P, Suri S, Shyam R, Kumria MM et al. (2001) Effect of an antidiabetic extract of Catharanthus roseus on enzymic activities in streptozotocin induced diabetic rats, J Ethno pharmacol 76(3): 269-277.

7. Sarabjot Kaur, Poonam Mondal (2014) Study of Total Phenolic and Flavonoids Content, Antioxidant Activity and Antimicrobial Properties of Medicinal Plants. Journal of microbiology and Experimentation 1(1): 1-6.

8. Shalini S, Prema Sampath kumar (2012) Phytochemical screening and antimicrobial activity of plant extracts for disease management. Int J Curr Sci 209-218.

9. Sheeraz ahamad wagay, Sudhansud Dhar Dwivedi, Manik Sharma Jagrati tripathi and Mushtaq ahmad (2013) Antimicrobial Activity of Catharanthus rosrus. Chemistry and Materials Research 3(9): 6163.

10. Govindaraji V (2007) PGR mediated in vitro metabolic engineering of alkaloid production in somatic explants of Catharanthus roseus (L.).

11. Asheesh Kumar, Singhal KC, Sharma RA, Govind K Vyas, Vinod Kumar (2012) Analysis of Antioxidant Activity of Catharanthus Roseus L. and it's 


\section{Bioequivalence \& Bioavailability International Journal}

Association with Habitat Temperature. Asian J Exp Biol Sci 3(4): 706-713.

12. Chinnavenkataraman Govindasamy, Rajendran Srinivasan (2012) In vitro antibacterial activity and phytochemical analysis of Catharanthus roseus (Linn.) G. Don. Asian Pacific Journal of Topical Biomedicine 155-158.

13. Kratika Kumari, Sharmita Gupta (2013) Phytopotential of Cathanthus Roseus L. (G.) Don. Var. "Rosea" And " Alba" Against Various Pathogenic Microbes In vitro. International Journal of Research in Pure and Applied Microbiology 3(3): 77-82.

14. Monika Sain, Vandana Sharma (2013) Catharanthus roseus- A Review of Potential Therapeutics Properties. Int J Pure App Biosci 1(6): 139-142.

15. Rischer H, Oresic M, Seppanen-Laakso T, Katajamaa, M. Lammertyn, M et al. (2006) Gene-tometabolite networks for terpenoid indole alkaloid biosynthesis in cathanthus roseus cells. Proceedings of the national Academy of sciences of the United States USA. 103(14): 5614-5619.

16. Jayanthi M, Sowbala N, Rajalakshmi G, Kanagavalli U, Sivakumar V (2009) Study Of AntiHyperglycemic Effect of Catharanthus Roseus In Alloxan Induced Diabetic Rats, International Journal of Pharmacy and Pharmaceutical Sciences 2(4): 114-116.

17. Veena Prajapati, Tripathi AK, Jain DC, Sharma S, Khanuja SPS (1998) Sensitivity of Spilarctia obliqua to Root Extracts of Catharanthus roseus. Phytotherapy Research 12(4): 270-274.

18. Alba Bhutkar MA, Bhise SB (2011) Comparative Studies on Antioxidant Properties of Catharanthus Rosea and Catharanthus. International Journal of Pharmaceutical Techniques 3(3): 1551-1556.

19. Som Nath Singh, PraveenVats, Shoba Suri, Radhey Shyam, Kumria MML (2001) Effect of an antidiabetic extract of Catharanthus roseus on enzymic activities in streptozotocin induced diabetic rats. J Ethnopharmacol 76(3): 269-277.

20. Ashutosh K Shukla, Ajit K Shasany, Madan M Gupta, Suman PS Khanuja (2006) Transcriptome analysis in Catharanthus roseus leaves and roots for comparative terpenoid indole alkaloid profiles. Journal of Experimental Botany 57(14): 3921-3932.
21. Kirtikar KR, Basu BD (1987) Mimosa Linn; In: Basu B D (Ed.), Indian medicinal plants. Periodical experts, New Delhi 2: 981.

22. Kokane Dnyaneshwar D, More RY, Kale MB, Nehete MN, Mehendale PC, et al. (2009) Evaluation of wound healing activity of root of Mimosa pudica. Journal of Ethnopharmacology 124(2): 311-315.

23. Chowdhury S A, Islam J, Flahaman Md M, Rahman Md M, Rumzhum N N et al. (2008) Cytotoxic, antimicrobial and anti-oxidant activities of the different plant parts of Mimosa pudica. S J Pharm Sci 1(1\&2): 80-84.

24. Girish KS, Mohanakumari HP, Nagaraju S, Vishwanath BS, Kemparaju K (2004) Hyaluronidase and protease activities from Indian snake venoms: neutralization by Mimosa pudica root extract. Fitoterapia 75(3-4): 378-380.

25. Ganguly M, Nirada Devi Rita Mahanta, Mridul K Borthakur (2007) Anti -fertility effect of Mimosa pudica. Contraception 76: 482-485.

26. Yesilada E, Kupeli E (2002) Berberis Crataegina DC; Root exhibits potent anti-inflammatory, analgesic and febrifuge effects in mice and rats. J Ethnopharmacol 79(2): 237-248.

27. Muthumani P, Meera R, Devi P, Koduri LV, Manavarthi S, et al. (2010) Phytochemical investigation and enzyme inhibitory activity of Mimosa pudica Linn. J Chem Pharm Res 2(5): 108114.

28. Pande M, Pathak A (2010) Preliminary pharmacognostic evaluations and phytochemical Studies on roots of Mimosa pudica (Laajvanti) Int J Pharm Sci Rev Res 1(1): 50-52.

29. Nazeema TH, Brindha V (2009) Antihepatotoxic and antioxidant defense potential of Mimosa pudica. Int J Drug Disc 1(2): 1-4.

30. Amalraj T, Ignacimuthu S (2002) Hyperglycemic effect of leaves of Mimosa pudica Linn. Fitoterapia 73(4): 351-352.

31. Chatterjee A, Pakrashi SC [2006] The Treatise on Indian Medicinal Plants. New Delhi: National Institute of Science Commission and Information Resources Pp: 65-66. 